\title{
焼酎白麴の各種酵素の活性調査について
}

\author{
岩野君夫・三上重明・福田清治・椎木 敏・島田豊明** \\ 小幡孝之*・木崎康造* - 新里修一* - 荒巻 功* ・ 佐伯 宏* \\ （国税庁醽造試験所・*熊本国税局鑑定官室・**現大阪国税局鑑定官室）
}

昭和 61 年 1 月 10 日受理

\section{Distribution of Enzyme Activities of Shochu Koji.}

Kimio IWANO, Shigeaki MIKAmI, Kiyoharu FUKUDA, Satoshi SHInOKI, Toyoaki SHIMADA,

Takaji OBATA, Yasuzo KIZAKI, Shuichi SHINZATO, Isao ARAMAKI and Hiroshi SAIKI

(National Research Institute of Brewing, 2-6-30, Takinogawa, Kita-ku, Tokyo 114)

Many shochu koji were collected from shochu makers in the south kyushu district and their various enzyme activities were investigated. The results shows that shochi koji has low $\alpha$-amylase activity (13\% of sake koji) and high activities of acid protease (13 times of sake koji) and transglucosidase ( 8 times of sake koji) and high activities of raw starch digestion.

The enzyme activities of shochu koji made of barley were lower than those made of rice, and especially the activities of transglucosidase, acid carboxypeptidase and acid protease were low.

Key words : 焼酎白赖, 酵素活性

\section{緒言}

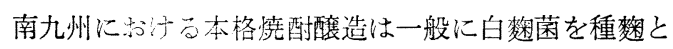
して製鿯し，白趋菌に酵素とともにクエン酸を生産さ せ，これによって醪を酸性とし，雑菌污染による腐造を 防いでいる。白整のみを原料とする一次醪はこの麵から のクエン酸により $\mathrm{pH} 3.2 \sim 3.5$ の強い酸性を示す1。 又, 焼酎の発酵は $24 \sim 34^{\circ} \mathrm{C}$ の高温で行なわれる。低い $\mathrm{pH}$ と高い温度という焼酎醪の環境は酵素反応にとって 厳しい条件で方るぶ，前報 ${ }^{2} に$ において白楼匊の $\alpha$-amylase (EC 3,2,1,1), glucoamylase (EC 3,2,1,3) 等はこのよ うな環境において極めて安定性が高いことを明らかにし た。

最近，㜔酎つ掛原料として米，麦，さつまいも以外に 多種多様のものぶ使用されるよらになった。これらの各 種原料の原料利用率の向上をはかるためには, 焼酎醪に おいて焼酎白䊍汇由来する各種加水分解酵素が担ってい る役割を明らかにする必要がある。今回，筆者らはまず 実際の焼酎製造に使われている白㲠はどの程度の酵素活 性を持っているわ調査することとした。

実際の焼酎醸造で使用されている白婪米の酵素活性の調 查については, 志垣ら ${ }^{31}$ が昭和 42 年に南九州の 24 酒造 場について製楼条件ならびに䴯の成分および醉素力を調
查し, 機械こうじ法と蓋こうじ法の違いと総合糖化力, $\alpha$-amylase 力との関係などについて検討している。

筆者らは，すでに $\alpha$-amylase と glucoamylase を正確。 に分別して活性を测定する方法を確立し4), 清酒猌およ び泡盛黒榃の活性調査を行った ${ }^{5,6)}$ 。今回も全く同一の方 法で南九州の焼酎製造場より白畨を集め, 各種酵素活性 の調査を行ったのでその結果を報告する。

\section{実 験 方 法}

\section{1. 焼酎白麴の採取}

熊本国税局管内の焼酎製造場より破砕精米を原料とし た白䊝（以下米咊と略す）については 20 場 27 点, 大 麦を原料とした白憗（以下麦䀜と略す）については 11 場 12 点, 合計 39 点の白棅を採取した。破砕精米はす べて政府米であったが，大麦は外国産精麦丸麦が 8 ，日 本産精麦丸麦が 3 ，半押麦が 1 の内訳であった。採取月

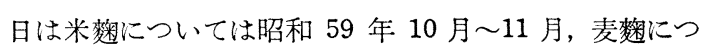
いては昭和 59 年 12 月〜昭和 60 年 3 月の間に行っ た。使用種憗はすべて白整菌であった。

\section{2. 水分, 酸度, でん粉価の分析}

水分はアルミ製のふた付ひょら量器に白麴を約 $10 \mathrm{~g}$ とり， $105^{\circ} \mathrm{C}$ で 5 時間乾燥し，デシケーター中で放冷後 減量を測定し，水分 $(\%)$ とした。 
酸度，でん粉価は国税庁所定分析法に準じた。

\section{3. 酵素活性の測定}

白麴の各種酵素活性として， $\alpha$-amylase (AAase), glucoamyase (GAase), transglucosidase (TGase, $3,2,1,20$ ), acid protease (APase, EC $3,4,23,6$ ), acid carboxypeptidase (ACPase, EC 3,4,16,1) および生 でん粉分解力 (RSD) の 6 種類の酵素活性を测定するこ

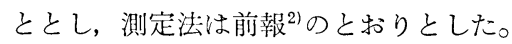

\section{実 験 結 果}

\section{1. 焼酎白麴の水分, 酸度およびでん粉価}

集めた焼酎白䴿の水分, 酸度およびでん粉価を調べた 結果をTable 1 にまとめて示した。

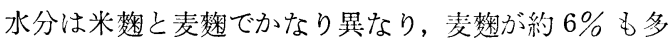
く, 変動率も高い。この事は大麦（精度丸麦）は吸水し やすいことを示し, 製造場によって洗麦, 浸漬の方法が かなり異なるものと推論される。

酸度は腐造防止の観点から経験的に 4.5 以上が必要 とされているが, Table 1 で明らかなように米榡の酸度

Table 1 Contents of water, acidity and starch value of shochu koji.
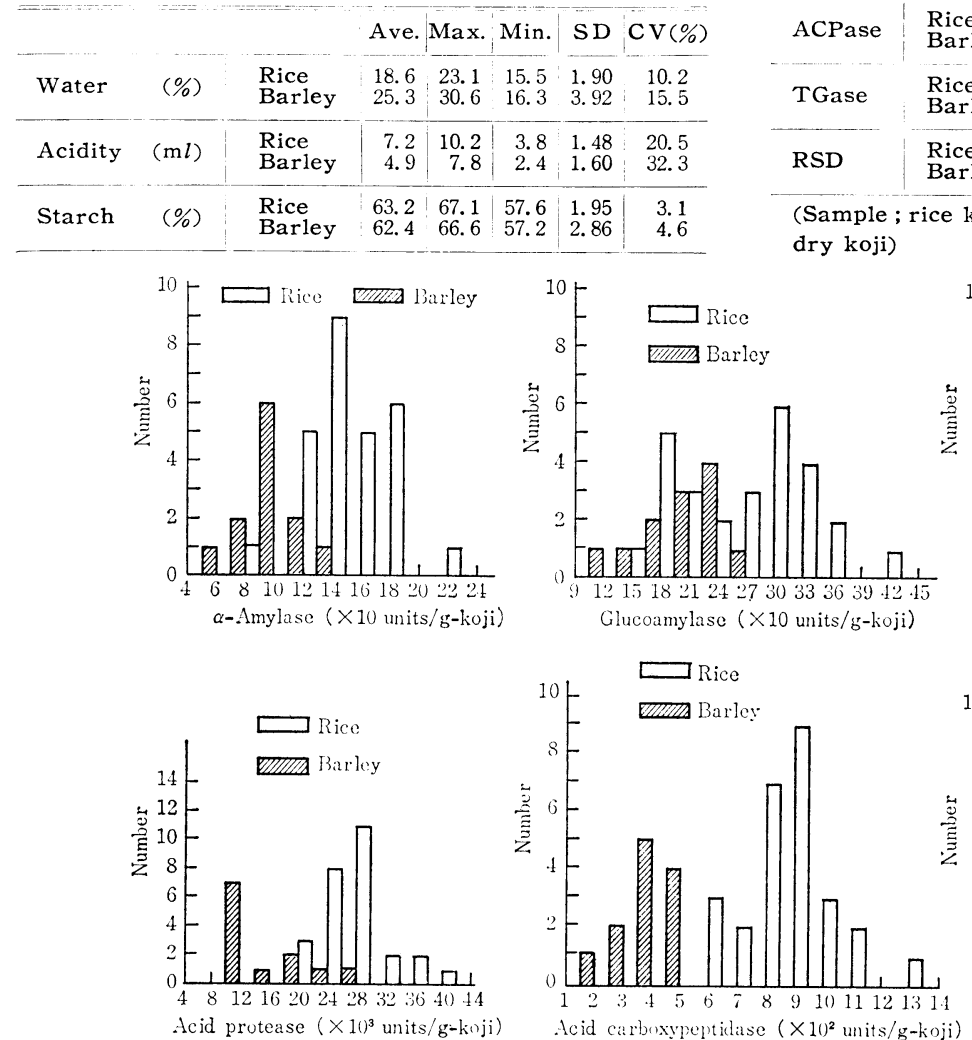

Fig. 1 Distribution chart of various enzyme activties of shochu koji
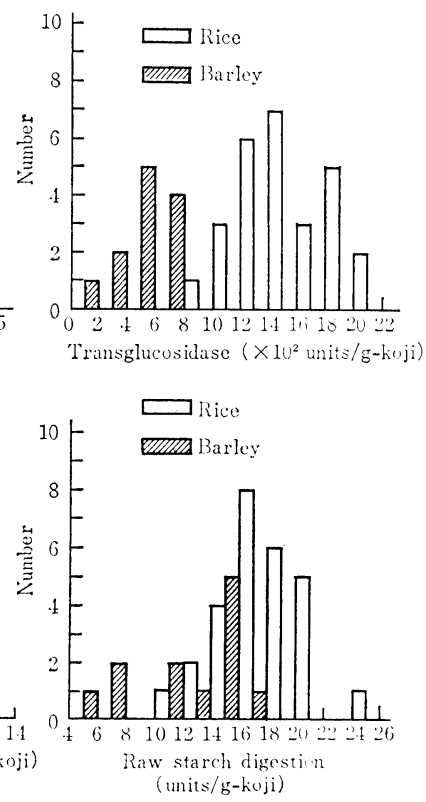

分布は平均 7.2 , 最大 10.2 , 最小 3.8 でほぼ必要量 を満足しているが，麦椓の酸度分布は平均 4.9, 最大

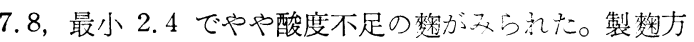
法と酸度との関係については，島田ら゙によって検討さ れ，製楼後半に低温経過をとる必要が方ると報告してい

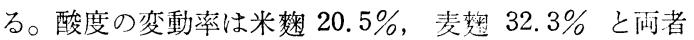
とも大きな值を示し, 製造場の違い:らって製䊝経過に 大きな違いがあることが推論される。

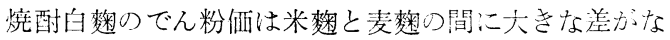
く平均 63\% であった。原料である破砕米や大翏のでん 粉洒は不明であるが，約 $74 \%$ とすれ㹈整中のでん 粉消費量は平均 11〜 $12 \%$ となり，島田ゔの示した $12.9 \%$ とほぼ一致した。

Table 2 Distribution of enzyme activities of shochu koji.

\begin{tabular}{|c|c|c|c|c|c|c|}
\hline & & Ave. & Max. & Min. & SD & $\begin{array}{l}\mathrm{CV} \\
(\%)\end{array}$ \\
\hline AAase & $\begin{array}{l}\text { Rice } \\
\text { Barley }\end{array}$ & $\begin{array}{r}159 \\
88\end{array}$ & $\begin{array}{l}223 \\
131\end{array}$ & $\begin{array}{l}95 \\
51\end{array}$ & $\begin{array}{l}27.6 \\
20.8\end{array}$ & $\begin{array}{l}17.3 \\
23.7\end{array}$ \\
\hline GAase & $\begin{array}{l}\text { Rice } \\
\text { Barley }\end{array}$ & $\begin{array}{l}282 \\
189\end{array}$ & $\begin{array}{l}442 \\
251\end{array}$ & $\begin{array}{r}170 \\
95\end{array}$ & $\begin{array}{l}70.5 \\
43.6\end{array}$ & $\begin{array}{l}25.0 \\
23.1\end{array}$ \\
\hline APase & $\begin{array}{l}\text { Rice } \\
\text { Barley }\end{array}$ & $\begin{array}{l}29,101 \\
13,933\end{array}$ & $\begin{array}{l}43,168 \\
25,168\end{array}$ & $\begin{array}{r}20,093 \\
8,551\end{array}$ & $\begin{array}{l}5,317.6 \\
5,604.5\end{array}$ & $\begin{array}{l}18.3 \\
40.2\end{array}$ \\
\hline ACPase & $\begin{array}{l}\text { Rice } \\
\text { Barley }\end{array}$ & $\begin{array}{l}9,224 \\
3,574\end{array}$ & $\begin{array}{r}13,241 \\
4,546\end{array}$ & $\begin{array}{l}6,266 \\
1,596\end{array}$ & $\begin{array}{r}1,537.5 \\
324.1\end{array}$ & $\begin{array}{l}16.7 \\
23.1\end{array}$ \\
\hline TGase & $\begin{array}{l}\text { Rice } \\
\text { Barley }\end{array}$ & $\begin{array}{r}1,524 \\
501\end{array}$ & $\begin{array}{r}2,196 \\
753\end{array}$ & $\begin{array}{l}830 \\
180\end{array}$ & $\begin{array}{l}338.5 \\
177.1\end{array}$ & $\begin{array}{l}22.5 \\
35.4\end{array}$ \\
\hline RSD & $\begin{array}{l}\text { Rice } \\
\text { Barley }\end{array}$ & $\begin{array}{l}17.7 \\
12.1\end{array}$ & $\begin{array}{l}24.8 \\
17.1\end{array}$ & $\begin{array}{r}11.2 \\
4.6\end{array}$ & $\begin{array}{l}2.9 \\
4.0\end{array}$ & $\begin{array}{l}16.6 \\
33.0\end{array}$ \\
\hline
\end{tabular}

(Sample ; rice koji 27, barley koji 12, Activity; units/gdry koji) 


\section{2. 焼酎白数の各種酵素活性の分布}

焼酎白䴴について 6 種類の酵素活性を測定し，平均 値，最大值，最小值等を Table 2 に，度数分布をFig. 1 に示した。酵素活性は乾燥数 $1 \mathrm{~g}$ 当りの活性として表 示した。

Table 2 から明らかであるが， 6 種類の酵素とも変動 罍が大きく，最大值と最小值を較べると平均で約 2.7 倍汪どの大きな差があった。この事は製造場ごとの製㛫 方法の違いが酵素生産に大きく影響していることを示す 马と考光られる。

最近，米憗のかわりに麦赖がかなり使用されるように なったが，麦麴と米䴯を酵素活性の面から比較すると Table 2, Fig.1 からも明らかなように麦麴はすべて の陼素活性が低い。特に大きな違いが認められたのは AAase, TGase, APase, ACPase であった。米粤の GAase はFig. 1 より明らかなように 2 つ山を持つ分 柚を示し，活性の低い米䊝群と麦憗が注ぼ同一の酵素活 怔分布を示した。

精麦大麦は吸水しやすく，製赖中は発熱しやすいなど 製麴操作の難かしいことが知られているが，何故麦粨の 酵素活性が低いのか今後検討する予定である。

Table 3 Correlation of various enzyme activities of shochu koji.

\begin{tabular}{|c|c|c|c|c|c|c|}
\hline & AAase & GAase & APase & ACPase & TGase $\mid$ & RSD \\
\hline AAase & 1.0 & & & & & \\
\hline GAase & $\begin{array}{l}0.647 * * * \\
0.824^{* * *}\end{array}$ & 1.0 & & & & \\
\hline APase & $\begin{array}{l}0.624^{* * *} \\
0.504^{*}\end{array}$ & $\begin{array}{l}0.518^{* *} \\
0.246\end{array}$ & 1.0 & & & \\
\hline ACPase & $\begin{array}{l}0.678^{* * *} \\
0.945^{* * *}\end{array}$ & $\begin{array}{l}0.602^{* * *} \\
0.845^{* * *}\end{array}$ & $\begin{array}{l}0.449^{* *} \\
0.380\end{array}$ & 1.0 & & \\
\hline TGase & $\begin{array}{l}0.859 * * * \\
0.870^{* * *}\end{array}$ & $\begin{array}{l}0.717 * * * \\
0.871^{* * *}\end{array}$ & $\begin{array}{l}0.582^{* * * *} \\
0.292\end{array}$ & $\begin{array}{l}0.733^{* * *} \\
0.900^{* * * *}\end{array}$ & 1.0 & \\
\hline RSD & $\begin{array}{l}0.761^{* * *} \\
0.518^{*}\end{array}$ & $\begin{array}{l}0.699 * * * \\
0.864^{* * * *}\end{array}$ & $\begin{array}{l}0.786^{* * *} \\
-0.005\end{array}$ & $\begin{array}{l}0.606^{* * *} \\
0.634^{*}\end{array}$ & $\begin{array}{l}0.749 * * * \\
0.792^{* * *}\end{array}$ & * 1.0 \\
\hline
\end{tabular}

Upper; rice koji $r(27,0.05)=0.323, r(27,0.01)=0.445, r(27$, $0.001)=0.568$

Down ; barley koji $r(12,0.05)=0.497, r(12,0.01)=0.658$, $r(12,0.001)=0.795$

\section{3. 各種酵素活性間の相関関係}

Table 3 は焼酎白麴の各種酵素活性間の相関関係をま とめたものである。米麳は各種酵素活性間のすべてに高 い相関関係が認められたが，麦菼米は幾分異なり APase と他の酵素との間の相関係数が小さく, AAase とのみ 危険率 5\% で有意の相関関係方認五られた。麦䴯の APase の生産のみが，このように他の酵素之無関係であ る理由については不明であるが，今後娭討する予定であ る。

米麴についてみれば，ずへての酸素活性間に正の高い 相関関係が認められたが，この事は酵菜活性の強い麥糔 すべての酵素活性が強く，弱い椟はすべての酵素活性が 弱いことを示すもので，製造場ごとの製䔩方法の違いが 大きく酵素生産に影響しているものと推論される。

4. 焼酎白棦の水分, 酸度, でん粉価と各種酵素活性 との相関関係

焼酎白棅の水分，酸度，でん粉価之各種酵素活性との 相関関係を調べた結果を Table 4 によとめた。

白䴯の水分と各種酵素活性との間に!さ全く相関関係は 認められなかった。酸度と各種酵素活性之の相関をみる と，米椈掞よび 麦麴とも酸度と GAase 活性との間に かなり高い正の相関関係が認められ，酸度の高い麴は GAase 活性も高い。この外，酸度之生でん粉分解力との 䦛にも相関が認められた。

白䊝のでん粉価と各種酵素活性との相関は麦麴につい ては全く相関関係がなく，米䀜については GAase, ACPase，TGase との間に負の相関関係が認められた が，その意味については不明である。

\section{考察}

筆者らは，今回用いた酵素活性の測定法と全く同一の 方法ですでに清酒麴および泡盛剓の酵素活性について調 查し報告している ${ }^{5,6)}$ 。そこで, 今回の焼酎白䴹の調査結 果と，すでに報告した清酒麴及び泡盛麴の調査結果を比 較してみたのが Table 5 である。

焼酎白䴯の AAase は清酒麳に較べて極めて活性が低 く，米楼で 8 分の 1 , 麦䊝で 14 分の 1 であった。この

Table 4 Correlation between the enzyme activities and the components of koji.

\begin{tabular}{|c|c|c|c|c|c|c|c|c|}
\hline & & & AAase & GAase & APase & ACPase & TGase & RSD \\
\hline Water & $(\%)$ & $\begin{array}{l}\text { Rice } \\
\text { Barley }\end{array}$ & $\begin{array}{l}-0.092 \\
-0.087\end{array}$ & $\begin{array}{r}-0.021 \\
0.253\end{array}$ & $\begin{array}{l}-0.125 \\
-0.357\end{array}$ & $\begin{array}{l}0.271 \\
0.151\end{array}$ & $\begin{array}{l}0.111 \\
0.033\end{array}$ & $\begin{array}{r}-0.088 \\
0.409\end{array}$ \\
\hline Acidity & $(\mathrm{m} l)$ & $\begin{array}{l}\text { Rice } \\
\text { Barley }\end{array}$ & $\begin{array}{l}0.311 \\
0.164\end{array}$ & $\begin{array}{l}0.534^{* *} \\
0.626^{*}\end{array}$ & $\begin{array}{r}0.163 \\
-0.216\end{array}$ & $\begin{array}{l}0.601^{* * *} \\
0.250\end{array}$ & $\begin{array}{l}0.374^{*} \\
0.484\end{array}$ & $\begin{array}{l}0.355^{*} \\
0.838^{* * *}\end{array}$ \\
\hline Starch & $(\%)$ & $\begin{array}{l}\text { Rice } \\
\text { Barley }\end{array}$ & $\begin{array}{r}-0.248 \\
0.214\end{array}$ & $\begin{array}{c}-0.475^{* *} \\
0.210\end{array}$ & $\begin{array}{r}-0.045 \\
0.440\end{array}$ & $\begin{array}{c}-0.566^{* *} \\
0.027\end{array}$ & $\begin{array}{c}-0.326^{*} \\
0.274\end{array}$ & $\begin{array}{r}-0.304 \\
0.243\end{array}$ \\
\hline
\end{tabular}

Rice koji ; $r(27,0.05)=0.323, r(27,0.01)=0.445, r(27,0.001)=0.568$ Barley koji $; r(12,0.05)=0.497 \quad r(12,0.01)=0.658, r(12,0.0001)=0.795$ 
Table 5 Comparison of enzyme activities among shochu koji, awamori koji and sake koji.

\begin{tabular}{lr:r|r|r} 
Enzymes & $\begin{array}{c}\text { Shochu } \\
(\text { rice }) \\
(\boldsymbol{n}=27)\end{array}$ & $\begin{array}{c}\text { Shochu } \\
\left(\begin{array}{l}\text { barley }) \\
(\boldsymbol{n}=12)\end{array}\right.\end{array}$ & $\begin{array}{c}\text { Awamori } \\
(\boldsymbol{n}=25)\end{array}$ & $\begin{array}{c}\text { Sake } \\
(\boldsymbol{n}=113)\end{array}$ \\
\hline AAase & 159 & 88 & 102 & 1,270 \\
GAase & 282 & 189 & 145 & 223 \\
APase & 29,101 & 13,933 & 17,529 & 2,285 \\
ACPase & 9,224 & 3,574 & 4,447 & 7,750 \\
TGase & 1,524 & 501 & 1,004 & 182 \\
RSD & 17.7 & 12.1 & 4.6 & - \\
\hline
\end{tabular}

(Activity; units/g-dry koji)

よらな低い活性でありながらしかも低い $\mathrm{pH}$ での醪に おいて, 焼酎原料が充分に溶解されている事実は驚異的 であり，この理由は前報で述べたように白数菌の生産す る AAase が酸性に叔いて極めて高い安定性と相対活性 を持っているためと考觉られる。

焼酎白䴴の GAase は清酒楚に較べるとほぼ同程度で あり，米麳はやや高く，麦麴はやや弱い程度である。

焼酎白釈の APase は清酒稳に較べると極めて高く,

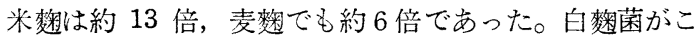
のように多くの APase を生産するのは, 原料の蛋白質 が多いことによるのか，分生子が付くまで老なすため か, あるいは菌自体の特性によるものか極めて興味のあ るところである。又, 清酒醪において, APase は AAase と蒸米との無効吸着を解消し間接的に蒸米の溶解に 対して大きな作用をしていることを筆者ら ${ }^{8)}$ が明らかに しているが焼酎醪においてこのよらな多量の APase が どのような役割を担っているか興味深く，現在検討中で 市る。

焼酎白麴の ACPase は清酒䅗と較べてみると米慗が やや多く，麦赖は約半分の活性である。

焼酎白麴の TGase は清酒醪と較べてみるとかなり高 く米䊝が約 8 倍，麦整が約 3 倍である。TGase は清酒 醪においてイソマルトース，パノ一ス等の非発醇性オリ ゴ糖や $\alpha$-エチル-D-グルコシドを造る働きをしてい る9)。こらの知見から TGase は焼酎醪において無用な 酵素のよらに考えられるが，このように多くの TGase が焼酎醪においてどのような役割を担っているか今後検 討する予定である。

生でん粉分解力 (RSD) は清酒醪にはほとんど活性が ないが，白麴にはかなりの活性が認められた。焼酎棦に おいてこの RSD が働いているのかどらか興味深い。
焼酎白棦と泡盛麳の酵素活性を較べてみると，活性の バランスはほぼ同様であるが，全体的にやや活性が弱 く，ほぼ麦楼と同程度の活性である。泡盛醸造は全棃仕 込みで，やや若目の整を使用するため，各種酵素活性が 低いものと考えられる。

\section{要 約}

南九州の焼酎製造場で実際に使用されている白麲を集 め, 各種酵素活性の調査を行ったところ以下の知見を得 た。

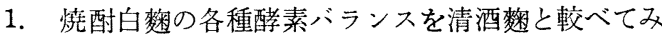
ると， $\alpha$-amylase が極端に低く, glucoamylase と acid carboxypeptidase はほぼ同程度, acid protease, transglucosidase が極めて高くかつ生でん粉分解力を有する のが特徵である。焼酎白䴯と泡盛䅗の酵素活性を較べて みると，活性のバランスはほぼ同様であるが，泡盛釈は 全体的にやや活性が低い。

2. 焼酎白敕は調べた 6 種類の酵素活性とも変動率が 17〜 $40 \%$ と大きく，最大值と最小值を較べると約 2.7 倍の大きな差があった。

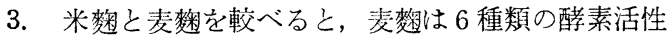
のすべてが低く, 特に $\alpha$-amylase, transglucosidase, acid protease に大きな違いが認められた。

終りに臨み，本実験に御協力をいただいた当研究室， 甲斐文男君，未広康夫君に，御指導を賜わりました当試 験所中村欽一所長に深謝致します。

\section{文献}

1）乙ょらちゅら醇造技術（財)日本醸造協会 (1983)

2) 岩野君夫, 三上重明, 福田清治, 椎木 敏, 島田 豊明：蠤協 81，（7）490（1986）

3) 志垣邦雄, 西谷尚道, 椎木 敏, 山川造一郎, 鈴 木昭紀：醸協 63，(11）1098（1968）

4) 岩野君夫, 風間敬夫, 布川弥太郎：醸協 71 , (5) $383(1976)$

5）布川弥太郎, 椎木 敏, 岩野君夫, 斉藤和夫 醸 協 76，（5）350(1981)

6）布川弥太郎, 岩野君夫, 椎木 敏 : 醸協 76, (5) 354 (1981)

7) 島田豊明, 志坦邦雄, 塚田定清, 戸塚 昭：醸協 59, (1) 74 (1964)

8）岩野君夫, 布川弥太郎 : 醸協 71, (12) 943 (1976)

9）岩野君夫, 柴田和宏, 布川弥太郎 : 醸協 72, (7) 521 (1977) 